\title{
Therapeutic Invariant Natural Killer T-cells
}

National Cancer Institute

\section{Source}

National Cancer Institute. Therapeutic Invariant Natural Killer T-cells. NCI Thesaurus.

Code C148557.

A preparation of natural killer T-cells (NKTs) expressing an invariant (alpha, beta) T-cell receptor (iNKTs), with potential immunomodulating and antineoplastic activities. Upon infusion of the therapeutic iNKTs, these cells recognize CD1d-restricted lipid lig ands, which are expressed on certain tumor cells, and secrete large amounts of various cytokines. This may activate the immune system against tumor cells. Additionally, iNKTs directly target and lyse tumor cells. 